\title{
Lumen
}

Selected Proceedings from the Canadian Society for Eighteenth-Century Studies

\section{Convention as Commentary in Edward Ravenscroft's The Careless Lovers}

\section{Robert Eggleston}

Volume 25, 2006

URI : https://id.erudit.org/iderudit/1012082ar

DOI : https://doi.org/10.7202/1012082ar

Aller au sommaire du numéro

Éditeur(s)

Canadian Society for Eighteenth-Century Studies / Société canadienne d'étude du dix-huitième siècle

ISSN

1209-3696 (imprimé)

1927-8284 (numérique)

Découvrir la revue

Citer cet article

Eggleston, R. (2006). Convention as Commentary in Edward Ravenscroft's The Careless Lovers. Lumen, 25, 133-144. https://doi.org/10.7202/1012082ar

Copyright @ Canadian Society for Eighteenth-Century Studies / Sociéte canadienne d'étude du dix-huitième siècle, 2006
Ce document est protégé par la loi sur le droit d'auteur. L'utilisation des services d’Érudit (y compris la reproduction) est assujettie à sa politique d'utilisation que vous pouvez consulter en ligne.

https://apropos.erudit.org/fr/usagers/politique-dutilisation/ 


\section{Convention as Commentary in Edward Ravenscroft's The Careless Lovers}

Written in great haste, in the course of scarcely more than one week if the author is to be believed, The Careless Lovers by Edward Ravenscroft debuted at the theatre in Dorset Garden on March 12, 1673. ${ }^{1}$ Although Ravenscroft had his share of success in the theatre with this play and others he wrote throughout the 1670s, '80s, and '90s, few critics have examined his dramatic output. ${ }^{2}$ Fewer still have commented on (let alone admired) The Careless Lovers. There are scarcely any dedicated studies of the play, and most commentary on it takes the form of passing remarks in larger, general studies which tend to summarize the plot and the play's salient features, to comment on Ravenscroft's plagiarizing

1 Edmund S. Henry, ed., Edward Ravenscroft's 'The Careless Lovers' and 'The Canterbury Guests': A Critical Old-Spelling Edition (New York: Garland, 1987), xxxii and 1-3 provides the first performance date and the epistle to the reader (published with the first edition in November 1673) in which Ravenscroft makes claims about the speed with which he wrote the play.

2 Between 1672 and 1697, Ravenscroft produced some twelve plays which enjoyed varying degrees of success. William Van Lennep, ed., The London Stage, 1660-1800. Part I: 1660-1700 (Carbondale: Southern Illinois University Press, 1965), 204 lists only the one known performance of The Careless Lovers, but acknowledges that there might have been more. In contrast, Van Lennep identifies five certain and two probable first-season performances of Ravenscroft's first play, The Citizen Turned Gentleman (1672), and quotes the dedication to the 1672 edition which suggests that the play was performed 'thirty times' (195). Further, two later Ravenscroft plays, The London Cuckolds (1681) and The Anatomist (1696), outlived their author and entered the repertory in the eighteenth century. In particular, The London Cuckolds earned a dubious status as a play performed annually on the eve of Lord Mayor's Day through until the 1750s. Frances M. Kavenik, British Drama, 1660-1779: A Critical History (New York: Twayne, 1995) indicates that The London Cuckolds achieved over one hundred performances by the 1750 s while The Anatomist managed over three hundred by the late 1770 s. 
Molière, and to note that the play's prefatory material formed part of a short-lived literary quarrel between Ravenscroft and John Dryden. ${ }^{3}$

That there is little sustained criticism devoted to the play is a pity, for The Careless Lovers stands as a model of ironic, sometimes socially radical, use of the standard stage clichés of the late seventeenth century, and as such it merits more attention than it has received. ${ }^{4}$ In its clever, mocking use of Restoration stock characters (the fop, the wealthy citizen, the tricky servant, and the prostitute), its laughable treatment of plot devices (disguise, cross-dressing, and the witty young lovers' proviso scene), and its sympathetic commentary on gender politics and class, the play employs the conventions of the age's drama, draws attention to those conventions' limitations, and turns them toward an examination of class-based and gender-based inequalities. ${ }^{5}$ This paper, then, will argue that in The Careless Lovers, Ravenscroft uses and abuses Restoration comedy's conventions in order to produce a play which is both an audience-pleasing farce and a considered analysis of stagecraft and social concerns in the early 1670s. To do so, it will examine Ravenscroft's treatment of characters such as Lord De Boastado (the sartorially excessive fop), Mr. Muchworth (the wealthy citizen), and Hillaria and Careless (the witty young lovers), his adultery-praising proviso scene, and

3 Passing commentary on The Careless Lovers appears, for example, in John Wilcox, The Relation of Molière to Restoration Comedy (New York: Columbia University Press, 1938), 133-34; John Harrington Smith, The Gay Couple in Restoration Comedy (Cambridge: Harvard University Press, 1948; New York: Octagon, 1971), 72-74; Robert D. Hume, The Development of English Drama in the Late Seventeenth Century (Oxford: Clarendon, 1976), 296-97; Derek Hughes, English Drama 1660-1700 (Oxford: Clarendon, 1996), 132-33; and J. Douglas Canfield, Tricksters and Estates (Lexington: University of Kentucky Press, 1997), 13-16. Dedicated studies include James G. McManaway, 'The Copy for The Careless Lovers,' Modern Language Notes 46 (1931): 406-09 and Henry, Critical Old-Spelling Edition.

4 The inclusion of The Careless Lovers in J. Douglas Canfield, ed., The Broadview Anthology of Restoration and Eighteenth-Century Drama (Peterborough: Broadview, 2001) might yet prompt interest in the play since it is now readily available for the first time in a modern edition. Unfortunately, Broadview's decision to exclude The Careless Lovers from the newer, concise edition of this anthology (2003) also suggests the play might continue to be ignored.

5 Hume, Development of English Drama, 297 notes Ravenscroft's mocking conventions in the play, and Hughes, English Drama, 133 notes the play's concern with class and gender, but neither discusses these topics in detail. Canfield, Tricksters and Estates, 15-16 describes the proviso scene between Careless and Hillaria as 'subversive,' a threat to 'Restoration political economy,' but he is not concerned as I am with how Ravenscroft uses convention and cliché as a means to literary and social commentary. 
his reversal of traditional gender and class roles throughout the play. In general, it is my hope that I can add to and modify received critical opinion of Ravenscroft's play somewhat, such that the author will appear as something better than 'a third-rate dramatist' (Allardyce Nicoll's damning assessment) and his play will merit praise above its deserving 'to be ranked at the top of comedies of the second class' where John Harrington Smith has long since placed it. ${ }^{6}$

There is no doubt that The Careless Lovers reads like a guide to late seventeenth-century stage clichés, for it is packed with the conventional plot elements and stock characters of the period - difficult parents are outwitted, fools are gulled, farcical scenes are played out, disguises are repeatedly employed, and the characters fall readily into the common categories of gay lovers, serious lovers, fops, tricky servants, obstructing parents, prostitutes, and so on. ${ }^{7}$ Borrowing in places from Molière's Monsieur de Pourceaugnac (1670) and Le Bourgeois Gentilhomme (1671), Ravenscroft's play presents the love intrigues and eventual marriages of two sets of young lovers, Careless and Hillaria, the initially antagonistic gay couple, and Lovell and Jacinta, the already attached serious lovers. ${ }^{8}$ A third pair of lovers, the servants Toby and Beatrice, never make it to the altar because Beatrice throws over Toby in favour of the foppish Lord De Boastado, whom she marries while she is in disguise. The wishes of the young lovers are opposed by Mr. Muchworth, father to Jacinta and uncle to Hillaria. Muchworth is a City alderman with upwardly mobile social aspirations who would have Jacinta abandon her long-standing attachment to Lovell in favour of marriage to De Boastado. The women are especially active in bringing about the various marriages, for example, donning disguise in order to orchestrate many of the schemes which fill out the action and lead to De Boastado's appearing acutely foolish and to his effective removal as a rival suitor. The play's close is light-

6 Allardyce Nicoll, Restoration Drama, 1660-1700, vol. 1 of A History of English Drama, 1660-1900, 4th ed. (Cambridge: Cambridge University Press, 1965), 256; Smith, Gay Couple, 72. Hume, Development of English Drama, 296 is somewhat more charitable in his assessment of the play, describing it as an 'engaging trifle.'

7 Hume, Development of English Drama, 127-33 summarizes the plot formulas and character types in the period's drama.

8 Ravenscroft's use of Molière in this and other plays is regularly commented upon. See, for example, Wilcox, Relation of Molière, 133-34; Nicoll, Restoration Drama, 254; and Henry, Critical Old-Spelling Edition, xxxi. That Ravenscroft also turned to Dryden's Secret Love (1667) as a source for his proviso scene in The Careless Lovers is noted by Henry, xxxii and Hume, Development of English Drama, 296. 
hearted, complete with free-wheeling proviso scene between Careless and Hillaria, and everyone, even the jilted Toby, the poorly-married De Boastado, and the outwitted Muchworth, is reconciled to the unions of the three pairs of lovers.

Ravenscroft's working so many conventions into The Careless Lovers is in line with the author's practice in his other plays and is partially responsible for his reputation among critics as a lightweight playwright whose only merit was in his knowing how to cater to his audience's tastes. ${ }^{9}$ And that assessment is not without justification, for apparently taking note of what went over well with audiences in other playwrights' plays, Ravenscroft filled his own with the same, never straying too far from the formulas that had worked well elsewhere. ${ }^{10}$ Never one to be accused of originality, Ravenscroft was content to follow the path others had worn, here, in The Careless Lovers, for example, using a structure that was common enough as he set up multiple plots with contrasting serious and lively pairs of lovers, a structure evident in many contemporary plays such as Etherege's The Comical Revenge (1664), Dryden's Secret Love (1667), Sedley's The Mulberry Garden (1668), and, later, Behn's The Rover (1677).

Fashion following would seem to be the intention in Ravenscroft's treatment of Lord De Boastado, his version of that common Restoration favorite, the fop. Ravenscroft's De Boastado does not enjoy the stature of, or receive the critical attention afforded to, other well-known Restoration fops such as Wycherley's Dapperwit and Monsieur de Paris, Etherege's Sir Fopling Flutter, or Cibber's Sir Novelty Fashion, yet he is every bit as ridiculous as his fashion-conscious brethren and deserves a greater place in the fop pantheon. ${ }^{11}$ Like many a Restoration fop, De

9 Varied comments on Ravenscroft's willingness to cater to his audiences and his contemporaries' reactions to that willingness appear in Nicoll, Restoration Drama, 254; Hume, Development of English Drama, 123; and Peter Holland, 'Farce,' in The Cambridge Companion to English Restoration Theatre, ed. Deborah Payne Fisk (Cambridge: Cambridge University Press, 2000), 118.

10 Ravenscroft's borrowings from Molière and Dryden's Secret Love alone prove the point, but as Hume, Development of English Drama, 123 notes, the author's plays 'are outstandingly unoriginal' even by the dramatic standards of the period.

11 Although many famous examples of the fop appeared in the years after The Careless Lovers was staged, Ravenscroft did have some models and, thus, an emerging convention to draw upon. The history of such fops is examined by Susan Staves, 'A Few Kind Words for the Fop,' Studies in English Literature 22 (1982): 413-28 and Robert Heilman, 'Some Fops and Versions of Foppery,' ELH 49.2 (1982): 363-95. Both authors discuss a wide range of fops in the period's plays, yet they fail to include commentary 
Boastado has social prominence which grants him a measure of power over those around him - he cannot simply be ignored. His wealth and title prompt deference in others (at least to his face) and even lead them to seek alliance with him as a means to their own upward social mobility, as in Mr. Muchworth's desire to have De Boastado as a son-in-law. Further, De Boastado performs one of the fop's common functions: he is the butt of ridicule throughout the play. At De Boastado's first appearance, Lovell sums up this count for Careless as 'the vain, idle, simple, conceited, impertinent, talking, traveling Lord De Boastado' and counsels 'Shun him as you would the plague. ${ }^{12}$ Lovell fleshes out the picture at Careless's request, noting that De Boastado

... values himself upon his traveling; many countries have taken notice of him, and he of a few. He passed them o'er as some men do a great library of books who read the title-page then turn to Finis. He carried more money out with him than he brought wit home. His observations are of modes, fashions, and women. He speaks some few words in most languages but sense in none. He has baptized himself with the honorable titles of most countries; his name is as long as a coach and six horses. ${ }^{13}$

In the scenes that follow, De Boastado reveals his vanity, stupidity, conceit, impertinence, and more. His coat of arms (complete with a griffin, a tiger, a camel, and an elephant) inappropriately mixes numerous heraldic devices and defies all the conventions of heraldry. His latest clothing purchase, which he proudly displays before Hillaria and Jacinta in act 2, combines fashions from the many countries he has visited and is the work of no less than twelve tailors of varying nationalities. He is easily gulled and mistreated by servants, prostitutes, and gentlewomen alike, while his own efforts at scheming or deceit are ineffective and only compound his woes. Thus, Toby dons disguise three times to deceive

on De Boastado. Similarly, De Boastado receives minimal attention in Andrew P. Williams, 'The Centre of Attention: Theatricality and the Restoration Fop,' Early Modern Literary Studies 4, no.3 (January, 1999), http:/ / purl.oclc.org/emls/04-3/

willfop.html. The character also has but two brief mentions in Andrew P. Williams, The Restoration Fop: Gender Boundaries and Comic Characterization in Later Seventeenth-Century Drama (Lewiston, NY: Mellen, 1995).

12 Edward Ravenscroft, The Careless Lovers, ed. Elizabeth Kraft, The Broadview Anthology of Restoration and Early Eighteenth-Century Drama, ed. J. Douglas Canfield (Peterborough: Broadview, 2001), 989. All subsequent references are to this edition. 
and belittle De Boastado (in act 4, scene 1 and twice in act 5, scene 1), two prostitutes, Breedwell and Clappam, handily drive De Boastado from the stage while denouncing him as a bigamist (act 4, scene 1), and Beatrice manages to marry him while he believes he has successfully schemed to marry a wealthy young woman (act 5 , scene 2 ). His marriage with Beatrice, moreover, is a consequence of his ready belief that any number of young women - in fact, all of the important young women in the play - are in love with him at one point or another. For all his efforts to master his world, De Boastado faces an ignominious end; this count finds himself married to Beatrice, a woman of gentle birth, admittedly, but nonetheless an impoverished one. In short, in every way that De Boastado values himself, he comes up wanting, and Ravenscroft effectively reduces him to farce long before the play is over. Indeed, that De Boastado becomes so ridiculous substantiates the complaints among Ravenscroft's contemporaries and modern critics that this author is but a writer of farce. ${ }^{14}$

Nonetheless, even if Ravenscroft does fall into farce and does not obviously stray too far from familiar stage conventions in his treatment of De Boastado, he does in the process rise above the heights of the third-rate and offer commentary beyond the trivial, here an observation which calls into question late seventeenth-century social norms and hierarchies: wealth, title, and access to culture and travel do not make a man admirable, and the well-born do not have a monopoly on these qualities in this play. For all his accomplishments and gentility, De Boastado is a fool, and in contrast it is the untitled gentlemen - Careless, Lovell, and even Mr. Muchworth - whose conduct proves them worthy of the audience's admiration. As Derek Hughes points out in a rare positive discussion of The Careless Lovers, Ravenscroft is 'one of the few dramatists before the 1690s to acknowledge the obvious enough fact that gentility both of conduct and ancestry could be found within ... [the City's] limits. ${ }^{15}$ At play's close, De Boastado announces his intention of retreating into self-imposed exile in the country with his new bride, and his imminent, scapegoat-like departure is Ravenscroft's signal that, social position notwithstanding, De Boastado is a blemish of poor behaviour and attitudes that merits expulsion from the play's otherwise unsullied City locale. Further, the treatment of De Boastado should

14 Nicoll, Restoration Drama, 254; Hume, Development of English Drama, 123; and Holland, 'Farce,' 118.

15 Hughes, English Drama, 132-33. 
garner more attention than it has to date because it is significant to a message that The Careless Lovers seems intent on imparting, as Hughes puts it, that 'gentility is not always to be found where one has been taught to look for it. ${ }^{\prime 16}$

If Ravenscroft's treatment of the foppish De Boastado goes some way towards forcing a reassessment of social hierarchies, much the same is true of his treatment of Mr. Muchworth. Muchworth, as obstacle to the happiness of Lovell and Jacinta, appears pretty much the standard senex, and little surprise were it if he were roundly defeated by the young lovers before play's close. However, although Muchworth is clearly a citizen (a character type mistreated elsewhere) who lives up to his name in his obsession with wealth, and he has some rather out-moded views of women (he dismisses disobedient young women as 'hair-brained' and deserving of cudgeling at the hands of their husbands ${ }^{17}$ ), he is neither ridiculed nor abused in any particularly vicious manner throughout the play. On the contrary, he appears a rather sharp-witted gentleman with a command of details, such as the value of Careless's estate (inherited some eight years earlier), and who can spot a trick as it is being played: when De Boastado believes that Hillaria is in love with him, Muchworth immediately recognizes that Hillaria is toying with the count - although he judiciously keeps that thought to himself for fear of offending. ${ }^{18}$ Muchworth also seems to be a father who earnestly wants to ensure his daughter is well-married, as when he says, without it appearing ironic at all, that his love for Jacinta makes him 'solicitous to see [her] . . . well-disposed ${ }^{\prime 19}$ in her marriage, and in general he is treated with some consideration. Certainly, in comparison to the abused De Boastado, Muchworth is hardly damaged at all, and this benign treatment reinforces the sense that Ravenscroft is promoting the middle classes' interests at the expense of their betters'. And even as a stage type (the heavy father), Muchworth escapes largely unscathed, pointing to Ravenscroft's not slavishly following conventions but rather varying them and underscoring their limitations. Muchworth has the opportunity to reconcile himself to the marriage of Jacinta and Lovell, and he does so with equanimity even before he learns of De Boastado's clandestine marriage to Beatrice. Ravenscroft's Muchworth, then, is simply not one of those

16 Hughes, English Drama, 133.

17 CL, 3.39-48.

$18 \mathrm{CL}, 3.287-380$.

$19 \mathrm{CL}, 3.8-10$. 
unreasonable and foolish father figures whom Jessica Munns identifies as deserving to be stripped of authority, a type that appeared with increasing frequency in the comedy of the $1670 \mathrm{~s}^{20}$ At play's close, it is De Boastado the count, not Muchworth the alderman, who is the play's biggest fool. ${ }^{21}$

Unconventional use of female characters is also a hallmark of Ravenscroft's play. Of the three important ones here, Jacinta, Hillaria, and Beatrice, Jacinta is the most like a stock character, the female young lover whose stage time is devoted to her negotiating her way toward marriage with Lovell. However, she is not entirely passive, nor does she simply look on while Lovell outwits her father. She is more than willing to participate in schemes aimed at disentangling herself from marriage to De Boastado, playing along with her father's commands in one scene, ${ }^{22}$ heaping scorn on De Boastado in another, ${ }^{23}$ but always behaving as the occasion merits. Like Jacinta, Beatrice is also a stock character, the typical tricky servant, and thus no wonder that she, too, is particularly active throughout the play. But at the same time she is unusual because her final trick elevates her from the realm of impoverished gentility to the title of Lady Beatrice when her marriage to Lord De Boastado is accepted without challenge. Tricky servants might often receive rewards for their services, but rarely do they succeed in orchestrating such social leveling or walking off stage at the top of the social hierarchy. Further, in his use of this stock type, Ravenscroft does point to the limited options available to a woman who is of good family but without the financial reserves to match: she can go into service as a governess to wealthy young women such as Jacinta and Hillaria and accept the prospect of marriage to a servant such as Toby or yet worse. With luck, though, she might be able to use her wits to escape her downward social slide, and Beatrice is unabashed in doing so. She is even able to manufacture a plausible

20 Jessica Munns, 'Change, Skepticism, and Uncertainty,' in Cambridge Companion (see note 8$), 144$.

21 Despite his benign treatment of Muchworth, Ravenscroft is not producing here a remarkably early, sympathetic version of the city alderman or merchant character such as would later appear in Sir Richard Steele's The Conscious Lovers (1722) or George Lillo's The London Merchant (1731). Indeed, Ravenscroft's The London Cuckolds (1681), which absolutely revels in the cuckolding of the city aldermen Doodle and Wiseacre, reveals that Ravenscroft is not particularly consistent in his treatment of this character type.

22 CL, 2.236-47.

$23 \mathrm{CL}, 3.312-72$. 
excuse and make herself appear selfless in tricking De Boastado into marriage because she claims she has done so 'purely out of kindness' to him, her sole desire being to help him escape marriage to one of Careless's cast off mistresses. ${ }^{24}$

Still more active and unconventional than either Beatrice or Jacinta is Hillaria. Her activities include initiating schemes designed to ridicule De Boastado and to secure the marriage of Jacinta and Lovell, protecting Jacinta from her father's dominance (at one point in act 4 she threatens to beat Muchworth with a cane), cross-dressing to get the upper hand with Careless, and standing up for the rights of women in general. Her battles with Muchworth are legion and often grow out of her demands that he recognize women's independence both in and out of marriage. '[M]an and wife are not one. For in this age they are seldom, or never together,' she asserts in response to Muchworth's comments on the nature of married couples. ${ }^{25}$ Muchworth believes her unmarriable for her humour, but she insists: 'I'll have women say and do what they will. Have not we rational souls as well as men. What made women mopes in former ages, but being ruled by a company of old men and women?'26 When Careless claims that he has interest in marrying Hillaria, Muchworth warns him that Hillaria is not someone he will get for a wife, but rather that she intends 'to get him for a husband. ${ }^{27}$ Hillaria is very much of this opinion, proclaiming 'If you won't commend me, I'll commend myself. And if I thought but half so well of him as I do of myself, we'd soon shake hands for to have and to hold without your leave. ${ }^{28}$ And just as Hillaria easily outmatches her uncle Muchworth, so too can she win the battle of wits with Careless, especially in one amusing scene in which she appears disguised as a young man (act 4, scene 3 ). The cross-dressing scene, of course, is a Restoration favourite, and Ravenscroft no doubt includes it for its stage appeal. However, Ravenscroft uses the convention to particular effect in that he has Hillaria abandon any pretense to feminine demureness, allowing her to don the man's clothes to control her man. As she had earlier abandoned traditional gender roles in threatening her uncle with physical violence, she does so again when she appears disguised as a man and quickly lures two prostitutes away from 
Careless; she becomes the more attractive man in the scene, and in the process she tricks Careless into admitting he loves her, effectively seizing control of their budding relationship. Hillaria will 'have women say and do what they will' and she does whatever she would do to her own advantage.

Hillaria's promoting a new way to rights for women is most apparent in the proviso scene she and Careless act out near the play's close. Confronted with Careless's public announcement of his intention to marry her, Hillaria responds by claiming disinterest. Although she knows that Careless loves her, Hillaria doubts his constancy and later publicly declares both her being against marriage in general and her preference for Careless as a gallant rather than as a husband. The result of her expressing this preference is that Careless finds himself in the unusual position of having to prove he is a card-carrying rake even as he is attempting to negotiate his marriage, and he is forced to appeal to the authority of two mistresses for verification of his lack of conscience. Hillaria, however, is not going to miss the opportunity to marry a man whom she does in fact love, and after worrying Careless for a time, she confesses her desire: 'Rather then [sic] lie alone tonight I'll do anything. ${ }^{29}$ Anything, though, is a qualified term on her part, for she immediately says she will be Careless's wife - that is, marriage must precede anything further happening between them. But she also adds 'since I can't have a gallant before marriage, I'll do like other wives and have one after' that is, she is not opposed to anything, including extramarital liaisons. ${ }^{30}$ Nonetheless, in order to maintain her appearances while enjoying such sexual freedoms, Hillaria recognizes the necessity of having a husband, 'if it is only to save the trouble of being asked questions o'er and o'er, as who's the father? who got it? ${ }^{31}$ In short, Hillaria's opening position on marriage is that it provides convenient cover for sexual indiscretions. Hillaria and Careless then launch into the various provisos which will govern their union, prominent among which are provisions for the mutual right to adultery. Hillaria demands that Careless adopt any illegitimate children she may bear. Careless counters that she must nurse any he fathers. Hillaria insists that Careless must befriend all her gallants and invite them home to dinner. Careless replies that Hillaria must acquaint herself with his mistresses, sing his praises to them, and even

29 CL, 5.2.338-39.

$30 \mathrm{CL}, 5.2 .341-43$.

31 CL, 5.2.344-46. 
assist him in his amorous activities: '[You are] to use the utmost of your power to bring us together, gain us an opportunity, and if need be, to watch at the stair head, and in case of necessity, to hold the door. ${ }^{32}$ With the incongruous final covenant that they shall always be polite and formal with one another rounding out the list, Hillaria declares their marriage 'must certainly be very pleasant and delightful. ${ }^{\prime 33}$ And pleased she must be, for through the course of this banter, Hillaria stakes out her rights and the space in which she can behave and live as she pleases, unencumbered by constraints imposed by a more jealous and less careless husband, a Lovell, for example.

Although Ravenscroft's proviso scene is meant as a laughter-provoking parody of the more decorous battle of wills between lovers in earlier plays, in particular Dryden's Celadon and Florimell in Secret Love, it has the same effect of equalizing the relationship between men and women and suggests serious intent. ${ }^{34}$ And Ravenscroft does seem entirely sympathetic to addressing inequalities between the sexes and the classes in his treatment of the women in the play. Obviously, there are exceptions to this claim, and one might be his treatment of prostitutes, for they do not rise much above stereotype, and although the play does draw attention to the conditions which force women into prostitution, it does not criticize those conditions but rather accepts them and the prostitutes' lot as but a feature of Restoration London. That said, though, the prostitutes Breedwell and Clappam are not without a measure of power, in that they can chase De Boastado from the stage with accusations of his having impregnated and secretly married them both. Neither woman is an Angelica Bianca figure, but each is able to gain a hearing of her tale of mistreatment - Breedwell supposedly abandoned with a young child and Clappam sold to slavery in Japan (act 4, scene 1) - and each has a laugh at her better's expense. In a precursor to De Boastado's unplanned marriage with Beatrice, Ravenscroft uses the prostitutes to precipitate the decline in De Boastado's prestige. In the process, Ravenscroft also manages to mitigate the sting of De Boastado's marriage to Beatrice because it is clear that his fate could be much worse than marriage to an impoverished gentlewoman - he would have been married to one of the prostitutes' peers had Careless had his way. Ravenscroft, then, has

32 CL, 5.2.364-67.

$33 \mathrm{CL}, 5.2 .378-79$.

34 The leveling effect inherent in such scenes is described by Kavenik, British Drama, 39-40. 
particular use for the stereotypical prostitutes beyond the laughter their various scenes generate.

In the end, that The Careless Lovers is farcical and bereft of deeper value in many places remains a fair criticism of the play, but those qualities also point to Ravenscroft's theatrical sense. Ravenscroft knew how to entertain an audience, and if that required introducing a scene in which De Boastado is pursued by prostitutes laden with his supposed bastard offspring, or if it involves the hapless, jilted Toby attempting to stab himself to death with a candlestick, so be it. But, utile et dulce, Ravenscroft achieves more than mere laughter with The Careless Lovers when he points mockingly at the limits of convention, yet uses convention to alert his audiences to truths they might do well to consider. And as such, the play deserves another look and more attention than it has received of late.

ROBERT EGGLESTON

University of British Columbia Okanagan 